\title{
RAPD analysis of grapevine hybrids and cultivars
}

\author{
Halász J., Korbuly J., Deák T. and Bisztray Gy. D. \\ Corvinus University of Budapest, Faculty of Horticultural Science, Department of Genetics and Plant Breeding, \\ 1118 Budapest, Ménesi út 44/A., Hungary \\ E-mail: gyorgy.bisztray@uni.corvinus.hu
}

\begin{abstract}
Summary: Utilization of the Randomly Amplified Polymorphic DNA (RAPD) technique as a molecular marker was tested to investigate the relationships between some representative grapevine cultivars and hybrids established at the Department of Genetics and Plant Breeding (CUB), to distinguish clones as well as to characterize various hybrids between species or cultivars and their parents. Vitis vinifera cultivars were easily and successfully distinguished by the RAPD technique and they were grouped according to the traditional taxonomic classification. RAPD patterns of the examined Pinot gris clones proved to be completely identical. Number of generations was reflected by the value of genetic distance of the examined hybrids. Genetic identity of parents and their offsprings was infiuenced by the selection applied in the process of plant breeding. Parental phenotypic and morphologic characteristics showed high degree of segregation in hybrids, but RAPD analysis revealed that their genetic similarity is considerable. The three Vitis amurensis clones were properly discriminated from every cultivar and hybrid of Vitis vinifera, i.e. hybrids are much closer to the cultivated grapevine than to V. amurensis due to the phenotypic selection carried out during the life-cycle of one or two generations.
\end{abstract}

Key words: cultivars, grapevine, hybrids, RAPD PCR, Vitis vinifera, Vitis amurensis

\section{Introduction}

Breeding of new Vitis vinifera varieties with higher economical value and greatest resistance to the most harmful pathogens is considered as a main interest in viticulture all over the world. Identification of the individual grapevine accessions involved in the breeding process requires accurate and reliable techniques. Formerly, it has been carried out on the basis of morphological characters (ampelography) or isozyme analysis. These methods are materially influenced by the environment, growth stages of plants and are limited in the amount of polymorphism, respectively, while the genome provides a source of constant primary characters. Randomly amplified polymorphic DNA (RAPD) was the first technique to exploit these advantages (Williams et al., 1990). Since the first report, this cheap, sensitive, easily applicable, automated RAPD analysis have been used in numerous scientific studies investigating a wide range of horticultural plants (Hu \& Quiros, 1991; Tingey \& del Tufo, 1993; Gogorcena \& Parfitt, 1994; Balogh et al., 2002; Belaj et al., 2002).

First data relating the successful distinction of grapevine cultivars by RAPD markers were published by Collins \& Symons (1993) and Jean-Jaques et al. (1993) who were able to differentiate eight cultivars involving Pinot noir, Cabernet sauvignon and Chardonnay.

RAPD technique allowed the reconsideration of the doubtful origin of Müller-Thurgau, which is one of the most important varieties in central Europe. High similarity of the RAPD PCR patterns validated Riesling as one of the parents of Müller-Thurgau, and rejected the assumption that Silvaner may be the other parent (Büscher et al., 1994).

Moreno et al. (1995) with only 14 decamer primers successfully discriminated 31 grapevine accessions supplied by Spanish germplasm banks, confirmed synonymies and detected a case of homonymy. Similar results were obtained in many other studies: DNA fingerprinting provided a potential tool to identify and discriminate several Greek (Stavrakakis et al., 1997), Italian or French (Fanizza et al., 2000; Schneider et al., 2001) and Turkish (Ergül et al., 2002) V. vinifera cultivars as well as German rootstock varieties (Wolf et al., 1998).

Most of the scientific efforts to differentiate among grapevine clones using RAPD markers remained unsuccessful (Collins \& Symons, 1993; Jean-Jaques et al., 1993; Ye et al., 1998), only Moreno et al. (1995) and Regner et al. (1998) were able to detect polymorphisms among certain clones.

The aim of the present study was to survey the applicability of the RAPD technique in investigating the relationships among some representative grapevine cultivars, distinguishing clones as well as characterizing various hybrids between species or cultivars and their progenitors established at the Department of Genetics and Horticultural Plant Breeding (CUB). 


\section{Material and method}

\section{Plant material and DNA isolation}

A total of 37 grape accessions, including 6 cultivars, 6 clones and 25 hybrids (Fig. 1.), were examined. Plant materials were obtained from the germplasm collection maintained at Szigetcsép. The interspecific cross between Vitis vinifera and Vitis amurensis species is used for the purpose of developing cultivars resistant or tolerant to powdery mildew, Peronospora or frost. Fully expanded young leaves were harvested from healthy shoots and kept at $-20{ }^{\circ} \mathrm{C}$ until it was used for DNA extraction. DNA was isolated following the protocol of DNeasy Plant kit (QIAGEN).
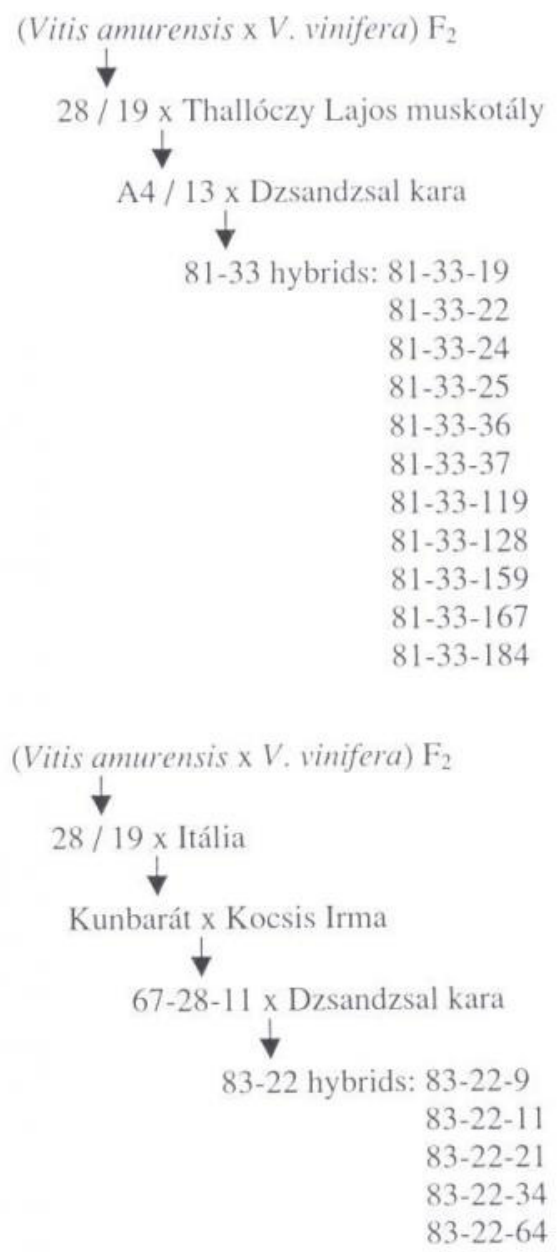

Figure 1. Origin of the tested hybrid families

\section{RAPD analysis}

The RAPD reactions were carried out in a volume of 25 $\mu$ l containing 1 Unit of RedTaq polymerase (D 6063, Sigma), $10 x$ buffer $(10 \mathrm{mM}$ Tris- $\mathrm{HCl} \mathrm{pH} 8.3 ; 10 \mathrm{mM} \mathrm{KCl} ; 1.5 \mathrm{mM}$ $\mathrm{MgCl}_{2}$ and $0.01 \%$ gelatine), $0.01 \mathrm{mM}$ each of dATP, dTTP, dGTP, dCTP, 50 pmol of primer and 40 ng of template DNA. The reaction mixture was overlaid with one drop of mineral oil. PCR was carried out in a MJ Research PTC 200
Thermocycler programmed as follows: one step of $3 \mathrm{~min}$ at $94{ }^{\circ} \mathrm{C}$, then 4 cycles of $20 \mathrm{~s}$ at $94^{\circ} \mathrm{C}, 1 \mathrm{~min}$ at $33^{\circ} \mathrm{C}, 1 \mathrm{~min}$ at $72{ }^{\circ} \mathrm{C}$, then 41 cycles of $20 \mathrm{~s}$ at $94^{\circ} \mathrm{C}, 1 \mathrm{~min}$ at $36^{\circ} \mathrm{C}, 1 \mathrm{~min}$ at $72{ }^{\circ} \mathrm{C}$ and a final step of $7 \mathrm{~min}$ at $72^{\circ} \mathrm{C}$. The amplification products were separated by electrophoresis in $1 \%$ agarose gels for $1.5 \mathrm{~h}$ at $120 \mathrm{~V}$ and detected by staining with ethidiume bromide. The stained gels were placed on a UV transilluminator and photographed with a Polaroid camera. A 100 bp ladder (Promega, G 210A) was used as a molecular size standard. Twenty five primers from kits A, B,C,O (Operon Technology, Alameda, Calif., USA) were assayed in the study.

\section{Statistical analysis}

RAPD profiles were scored visually. The position of scorable RAPD bands was transformed into a binary character matrix (' 1 ' for the presence and ' 0 ' for the absence of a band at a particular position). Only reproducible and well-defined bands in each of the three replications were considered as potential polymorphic markers. Genetic similarity between each pair of accessions and the dendrogram tree were calculated using POPGENE (ver 1.32) software package (Yeh et al., 1999). Nei formula (1972) was used for estimating genetic distance among genotypes. Results are represented as dendrograms based on agglomerative group forming. The dendrogram shows the similarities between the analyzed hybrids and cultivars.

\section{Results and discussion}

\section{Vitis vinifera cultivars}

Six cultivars were tested to control the RAPD analysis. Sixteen primers from OPA series were used for RAPD fingerprinting of the six grapevine genotypes. OPA 1, 2, 3, 4, $5,8,9,11,12,13,14,15$ primers provided consistent results in three parallel analyses. 106 bands were distinguished. The number of bands per primer ranged from 4 to 11. After the results were gathered in a data matrix, we applied the software POPGENE to evaluate our results. The greatest ranges of similarity values were shown between Iszpiszár-Icskimár and Furmint-Hárslevelü (0.2326). The lowest similarity values were obtained between Iszpiszár-Hárslevelü and Pinot noir-Hárslevelü (0.5691). The six cultivars were classified into three groups as it is demonstrated by the dendrogram (Fig. 2). This classification was equal with Negrul's system so evidence of relationships for the cultivars according to their geographic origins has been found:

1. Convarietas pontica: Furmint and Härslevelü.

2. Convarietas occidentalis: Chardonnay and Pinot noir.

3. Conavarietas orientalis: Iszpiszár and Icskimár.

RAPD proved to be a suitable tool to distinguish species of the Muscadinia subgenus from species of the Euvitis subgenus (Wang et al., 1999). 


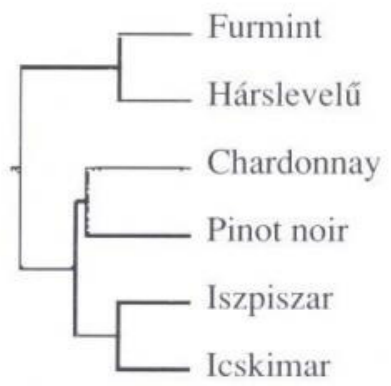

Figure 2. Dendrogram of the Vitis vinifera cultivars indicating the three proles in compliance with Negrul's system.

\section{Pinot gris clones}

With 40 primers (OPA 1-20 and OPB 1-20) a total of 211 bands were generated from the genomic DNA of six genotypes. Since no polymorphysms were detected the six clones were indistinguishable in this and other studies (Collins \& Symons, 1993; Jean-Jaques et al., 1993; Ye et al., 1998), as well. The inability to separate clones may be attributable to the rarity of genetic changes responsible for clonal identity, which would make the detection of these changes highly improbable.

\section{Relationships of hybrids}

RAPD technique proved useful as a sensitive and reliable method to identify grapevine cultivars and hybrids and to examine their origin and relationship. In our experiments Operon A, C, O primers were used. Altogether 23 primers were tested whereof OPA 1, 2, 3, 4, 5, 8, 9, 11, 12, 13, 14, 15; OPC 5, 6, 9, 16 and OPO 10,11, 19 primers provided consistent results in three parallel analyses. These 19 primers yielded 145 well distinguishable bands (Fig. 3.). High genetic polymorphism was reflected by the diversified RAPD patterns, which agrees with results of previous studies carried out in different grapevine taxons with RAPD during the last 10 years (Collins \& Symons, 1993; Jean-Jaques et al., 1993; Moreno et al., 1995; Stavrakakis et al., 1997; Fanizza et al., 2000).

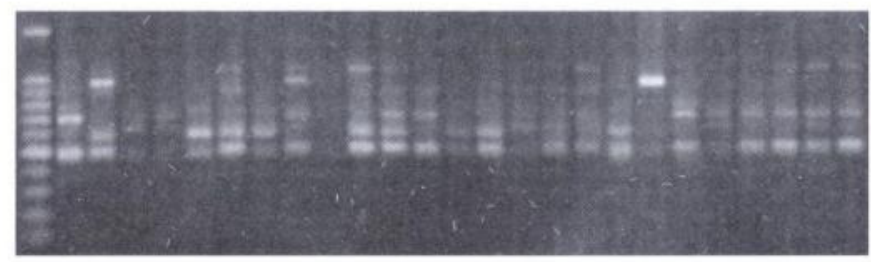

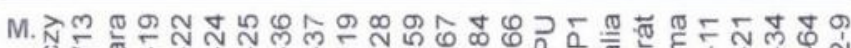

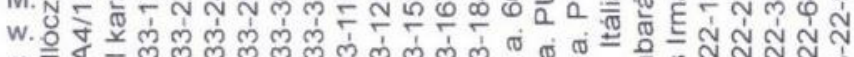
m. I N 营

Figure 3. RAPD profiles of grapevine leaf extracts yielded by primer OPC-6. M. w. m.: Molecular weight marker
Small genetic distances occured among the individual $V$. amurensis clones $(0.2103 ; 0.2318 ; 0.2538)$. Between the hybrids of the 81-33 group RAPD analyses revealed nearly identical genetic distances. The greatest value was only 0.4098 characterizing the relationship between the 81-33-22 and the 81-33-128 hybrids. Genetic distance showed the lowest value between the hybrids $81-33-25$ and $81-33-36$ $(0.1385)$.

As being one of the parents, A4/13 shows only a small genetic distance from the 81-33 hybrid family $(0.2318-$ 0.4098). It is close to Thallóczy Lajos muscat as its direct parent and 81-33-25 hybrid as its direct offspring as well (0.2318).

Dzsandzsal kara is a progenitor of both hybrid families, which is clearly demonstrated by its genetic distances from them: values from the $81-33$ family are ranging from 0.2538 to 0.3716 . In case of the 83-22 family values are between 0.4098 and 0.5051 . Most offsprings of Dzsandzsal kara appeared to be more closely related to the other parent because the selection was directed to such a resistance (resistant to frost or Peronospora infection) which had the other parent. The individual members of the 83-22 family are relatively closer to Kocsis Irma $(0.2763-0.4631)$ as a Vitis vinifera cultivar than Kunbarát $(0.4495-0.5792)$ as an interspecific hybrid. In case of Kunbarát it can be observed well that the degree of similarity with its direct parent (Itália) was much higher $(0.4495)$ than with its Vitis amurensis grandparent $(0.6761)$. The distance from progenitors expressed in generations is reflected by the value of genetic distance from progenitors.

As Figure 4. shows two main groups were formed: the three tested $V$. amurensis accessions were grouped together and well segregated from the other main group gathering the $V$. vinifera cultivars and hybrids. It proves that during some generations the hybrids got very closely related to cultivated grapevine for the results of phenotypical selection during the breeding process. The high similarity and clustering among all of the $81-33$ hybrids is due to their common origin. The low distance values of $\mathrm{A} 4 / 13$ from these hybrids show being one of their parents.

83-22 hybrids are much closer to the wild species than members of the 81-33 family. In the dendrogram these hybrids locate next to each other, between their parents. Six hybrids make a smaller group; they rather resemble to A4/13 than Dzsandzsal kara. 83-22 hybrids became settled into a block, they are more distant from their direct parent (Dzsandzsal kara) than their progenitors (Kunbarát, Kocsis Irma).

In tested hybrid families the morphological and phenotypical characteristics of their parents show wide range of segregation, although their similarity at the genotype level was significant. Former studies by $Y e$ et al. (1998) noted the same results testing Vitis vinifera and $V . \times$ Labruscana cultivars. Identification of parents by RAPD markers was successful in case of other grapevines (Büscher et al., 1994; Regner et al., 1998). The number of tested primers is not enough to prove all progenitor-offspring relationships but 


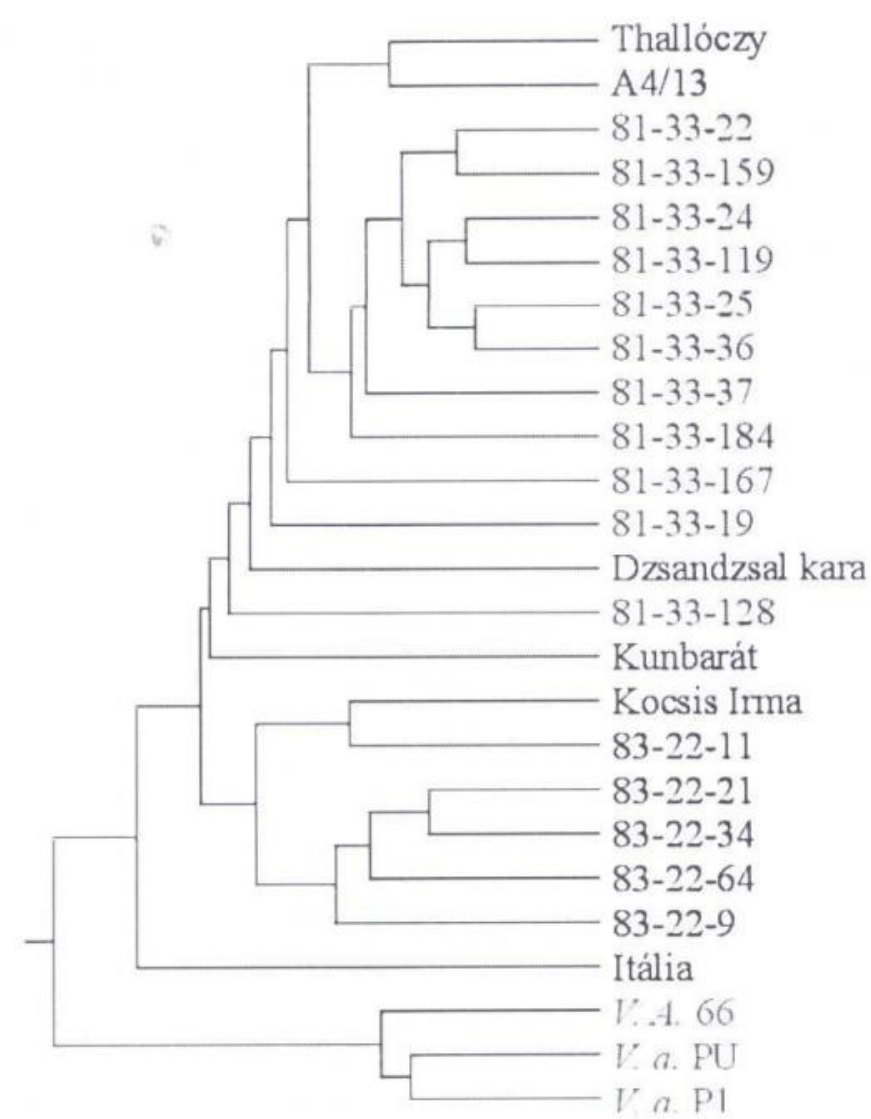

Figure 4. Dendrogram obtained by cluster analyses illustrating the relatedness of hybrids and their progenitors

using further primers can make possible to confirm the reality of the registered parents.

\section{Acknowledgements}

The authors are grateful to Mrs. Bacskai Papp Anna and Tóth Vera for their skilful technical assistance.

\section{References}

Balogh A., Kiss E., Szöke A., Dénes F. \& Heszky L. (2002): Molecular analysis of strawberry cultivars using RAPD, AP-PCR and STS markers. Horticult. Sci., 8: 24-28.

Belaj, A., Satovic, Z., Rallo, L. \& Trujillo, I. (2002): Genetic diversity and relationships in olive (Olea europaea L.) germplasm collections as determined by randomly amplified polymorphic DNA. Theor. Appl. Genet., 105: 638-644.

Büscher, N., Zyprian, E., Bachmann, O. \& Blaich, R. (1994): On the origin of the grapevine variety Müller-Thurgau as investigated by the inheritance of random amplified polymorfic DNA (RAPD). Vitis, 33: 15-17.
Collins, G. G. \& Symons, R. H. (1993): Polymorphisms in grapevine DNA detected by the RAPD PCR technique. Plant Mol. Biol. Reptr., 11: 105-112.

Ergül, A., Marasali, B. \& Agaoglu, Y. S. (2002): Molecular discrimination and identification of some Turkish grape cultivars (Vitis vinifera L.) by RAPD markers. Vitis, 41: 159-160.

Fanizza, G., Corona, M. G. \& Resta, P. (2000): Analysis of genetic relationships among Muscat grapevines in Apulia (South Italy) by RAPD markers. Vitis, 39: 159-161.

Gogorcena, Y. \& Parfitt, D.E. (1994): Evaluation of RAPD marker consistency for detection of polymorphism in apricot. Sci. Hortic., 59:163-167.

Hu, J. \& Quiros, C. F. (1991): Identification of broccoli and cauliflower cultivars with RAPD markers.Plant Cell Rep., 10: 505-511.

Jean-Jaques, I., Defontaine, A. \& Hallet, J. N. (1993): Characterization of Vitis vinifera cultivars by Random Amplified Polymorfic DNA markers. Vitis, 32: 189-190.

Moreno, S., Gogorcena, Y. \& Ortiz, J. M. (1995): The use of RAPD markers for identification of cultivated grapevine (Vitis vinifera L.). Sci. Hortic., 62: 237-243.

Regner, F., Sefc, K., Stadlbauer, A. \& Steinkellner, H. (1998): Genetic markers for the identification of varieties and clones as a guarantee of quality. Proc. IS on Production of Quality Wine. E. Hajdu (ed.), Acta Hort., 473: 49-58.

Schneider, A., Carra, A., Akkak, A., This, P., Laucou, V. \& Botta, R. (2001): Verifying synonymies between grape cultivars from France and Northwestern Italy using molecular markers. Vitis. 40: 197-203.

Stavrakakis, M. N., Biniari, K. \& Hatzopoulos, P. (1997): Identification and discrimination of eight greek grape cultivars (Vitis vinifera L.) by random amplified polymorphic DNA markers. Vitis, 36: 175-178.

Tingey, S. V. \& del Tufo, J. P. (1993): Genetic analysis with random amplified polymorfic DNA markers. Plant Physol., 101: 349-352.

Wang, Y., Chen, J., Lu, J. \& Lamikanra, O. (1999): Randomly amplified polymorhic DNA analysis of Vitis species and florida bunch grapes. Sci. Hortic., 82: 85-94.

Williams, J. G. K., Kubelik, A. R., Livak, K. J., Rafalski, J. A. \& Tingey, S. V. (1990): DNA polymorphisms amplified by arbitrary primers are useful as genetic markers. Nucleic Acids Res., 18: 6531-6535.

Wolf, T., Eimert, K., Bleser, E. \& Ries, R. (1998): PCR/RAPD to determine the genotype of wooden rootstock cuttings. Proc. IS on Production of Quality Wine. E. Hajdu (ed.), Acta Hort., 473: $41-45$.

Ye, G. N., Soylemezoglu, G., Weeden, N. F., Lamboy, W. F., Pool, R. M. \& Reisch, B. I. (1998): Analysis of the relationship between grapevine cultivars, sports and clones via DNA fingerprinting. Vitis, 37: 33-38. 